\title{
USHUL AL-NAHWI: Kajian tentang Dasar Bangunan Sintaksis Arab
}

\author{
Abdullah Zainur Ra'uf \\ Penulis adalah Dosen Universitas Islam Negeri (UIN) Malang
}

\section{ABSTRACT}

Muhammad Ahmad Qasim argued that ushul al-nahwi is a study about nahwu propositions (Arabic syntax) in general from either its reasoning and method. It is mainly regarded as reference as many linguists meet linguistics problems about nahwu. Each language, generally known, has structure and pattern so systematic that it can clearly understandable and acceptable to people. Moreover, the differences within ushul al-nahwi many linguistics meet can basically be referred to two main ways; alsima' and al-naqli.

\section{Pengantar}

Kemampuan berbahasa merupakan salah satu pembeda utama antara manusia dan binatang. Dengan kemampuan berbahasanya sehingga manusia disebut al-hayawan al-natiq, hewan yang berbicara (berpikir). Predikat ini menunjukkan bahwa suatu masyarakat manusia selalu diikat oleh bahasa yang mereka gunakan. Dengan demikian, setiap masyarakat terbentuk, hidup, dan tumbuh dengan bahasa. Dan dengan bahasa itu mereka bisa berkomunikasi, menyampaikan keiinginannya, serta saling tukar informasi. 
Dalam berkomunikasi agar sebuah pesan yang disampaikan dapat diterima dan direspon dengan baik, maka bahasa harus tunduk pada kaedah-kaedah yang sudah ada. Karena setiap bahasa memiliki kaedah atau gramatika yang baku, baik itu sudah terkodifikasi maupun belum. Dalam bahasa Arab misalnya, tokohtokoh seperti Abu al-Aswad al-Duali, Kholil bin Ahmad, Syibawaih, al-Kisa'i, alFarra', Tsa'lab, Ibn Syaqir, Ibn al-Khoyyat, dan lainnya adalah pioner dan tokoh linguis Arab. ${ }^{1}$ Mereka sangat berjasa dalam mengumpulkan dan membukukan kaedah-kaedah bahasa Arab pada masa-masa berikutnya.

Aliran atau madrasah Baghdad yang berkembang subur untuk kajiankajian sintaksis, maupun morfologi di Indonesia juga tidak bisa dilepaskan dari aliran-aliran sebelumnya, yaitu aliran Bashrah dan Kuffah serta peran dari tokoh linguis di atas. Kedua aliran ini sebagai embrio munculnya aliran Bahgdad yang hingga sekarang tetap eksis untuk dijadikan rujukan dalam memberikan solusi terhadap permasalahan dan perbedaan tata bahasa. Memang ada perbedaan metodologi yang cukup mendasar antara keduanya, dan perbedaan itu sering kali dipaparkan oleh para tokoh ( $n$ uhhat) aliran Baghdad beserta argumentasi masingmasing. Namun karena kekuatan politik barangkali, sehingga aliran Baghdad bisa mempertemukan dan mengkorvengensi pikiran-pikiran yang berbeda, sekaligus mengkofidikasi dalam sebuah karya besar, seperti Alfiyah Ibn Malik.

Dari deskripsi di atas, tulisan ini tidak membicarakan perbedaan metodologi antara aliran Bashrah, Kufah maupun Baghdad, namun dalam keterbatasan, baik mengenai referensi maupun kemampuan penulis maka dalam tulisan ini penulis ingin mengkaji kembali sumber-sumber atau dasar-dasar pengambilan kaedah tata bahasa Arab, yaitu ushul al-nahwi: dasar-dasar bangunan sintaksis Arab.

\section{Ushul al-Nahwi (Dasar Bangunan Sintaksis Arab)}

Mengutip pendapat Muhammad Ahmad Qasim, yang dimaksud dengan ushul al-nahwi ialah ilmu yang mengkaji tentang dalil-dalil nahwu (sintaksis Arab) secara global, baik dari aspek dalil itu sendiri maupun metode pengambilannya. ${ }^{2}$ Ia menyerupai undang-undang yang menjadi rujukan bagi seorang hakim ketika memutuskan perselisihan dalam suatu masalah. Juga dengan ushul al-nahwi, ia akan menjadi marji ' ketika para linguis Arab menghadapi perbedaan pendapat seputar permasalahan nahwu.

Ulul Albab, Vol. 5 No. 2, 2004 
Ushul al-nahwi merupakan dasar pijakan dan sandaran dalam merumuskan kaedah-kaedah tata bahasa Arab. Karena setiap bahasa harus memiliki susunan yang teratur dan berpola sehingga membentuk suatu keseluruhan yang bermakna dan berfungsi. Sistem ini dibentuk oleh sejumlah unsur atau komponen yang satu dengan lainnya berhubungan secara fungsional. Sebagai sebuah sistem, bahasa itu sekaligus bersifat sistematis dan sistemis. Sistematis artinya bahasa itu tersusun menurut suatu pola, tidak tersusun secara sembarangan. Sedangkan sistemis artinya bahasa itu merupakan sistem tunggal, tetapi juga terdiri dari sub-sub sistem, atau sistem bawahan. ${ }^{3}$

Karena itu, dalam bahasa Arab kajian mengenai sub-sub sistem bahasa seperti fonologi (ilm al-aswat), morfologi (ilm al-sharf), sintaksis (ilm al-nahw) dan semantik ( $\mathrm{ilm}$ al-dilalah) memiliki aturan-aturan dan pola tertentu yang secara keseluruhan membentuk satu sistem. Kajian semua ini mempunyai rujukan yang kuat sehingga wujud bahasa yang disampaikan tidak keluar dari aturan yang ada dan akan memberikan pemahaman yang jelas.

Ada banyak perbedaan pendapat mengenai ushul al-nahwi, misalnya Ibn Jinni, ia mengatakan ushul al-nahwi ada tiga, yaitu (i) al-sima', (ii) al-ima'dan (iii) al-qiyas. Sementara al-Anbari menyebutkan juga ada tiga, tetapi ada perbedaan antara keduanya, yaitu (i) al-naql, (ii) al-qiyas dan (iii) istishhabul hal. Dengan kepandaiannya, al-Suyuthi mampu menggabungkan dari kedua pendapat di atas bahwa ushul al-nahwi ada empat, yaitu; (i) al-sima;, (ii) alijma;, (iii) al-qiyas, dan (iv) istishhabul hal. ${ }^{4}$

Perbedaan dalam menetapkan dasar bangunan sintaksis Arab atau nahwu ini sesungguhnya dapat dikembalikan kepada dua macam cara, yaitu al-sima dan al-qiyas. Karena kedua cara ini merupakan langkah awal dalam melakukan kajian dan penelitian mengenai kaedah-kaedah nahwu.

Para linguis Arab di dalam menggunakan cara di atas mereka mengembangkan satu metode yang akurat, yaitu metode induktif. Di mana metode ini mereka gunakan dengan cara meneliti pembicaraan orang-orang Arab yang fasih. Akan tetapi dikarenakan kondisi waktu dan tempat yang tidak memungkinkan untuk diterima secara langsung atau oral maka mereka banyak melakukan penelitian terhadap teks-teks yang disampaikan melalui transmisi ( $a l$-naql). Dan itu pun harus mencapai jumlah banyak orang yang dapat dipercaya (tsiqah) sehingga hasil penelitiannya bisa dijadikan sandaran yang valid. Informasi-informasi 
(al-manqul) yang mereka peroleh dengan cara mendengarkan pembicaraan orangorang Arab yang tidak diragukan tentang kefasihannya di kalangan ahli tata bahasa Arab dikenal dengan sebutan $a l$-sima: ${ }^{5}$ Dan kefasihan dalam berbicara menjadi salah satu syarat dalam membuat kaedah-kaedah nahwu sehingga teks-teks tersebut terhindar dari akulturasi (indimaj) dengan bahasa-bahasa lain. ${ }^{6}$ Karena itu, ungkapan yang fasih hanya bisa diperoleh dari al-Qur'an, hadis dan kalam $a l$-'arab.

\section{Al-Quran}

Yang dimaksud dengan al-Qur'an sebagai dasar rujukan ilmu nahwa adalah bukan teks-teks yang ada secara keseluruhan, melainkan dari sisi pembacaan yang terdapat perbedaan dalam melafadzkan huruf-hurufnya dan susunan tata bahasanya. Dan kita memaklumi, bahwa perbedaan pembacaan ini semuanya dinisbatkan dan bersumberkan kepada Nabi saw.

Para pakar bahasa berargumentasi bahwa apa yang dibaca dari ayat-ayat al-Qur'an memang ada yang mutowatir, ahad dan bahkan ada yang syadz. Mereka sangat berhati-hati dalam menerima informasi yang berkaitan dengan cara pembacaan al-Qur'an. Tidak hanya terbatas kepada informan apakah cara membacanya itu fasih atau tidak, namun kebersambungan sanad (transmisi) juga sangat menentukan terhadap sahihnya pemberitaan. Begitu sulitnya untuk mendapatkan pembacaan al-Qur'an seperti persyaratan di atas maka wajar kalau dalam membaca al-Qur'an terjadi perbedaan-perbedaan yang kesemua itu mempunyai rujukan. Sebab itulah para pakar bahasa tidak hanya membatasi kepada berita yang mutawatir saja, tetapi mereka juga mengakomodasi pembacaanpembacaan yang syadz dengan syarat apabila tidak bertentangan dengan qiyas. ${ }^{7}$ Diantara bacaan-bacaan yang zyadz adalah;

i. Di dalam mushaf Umar ibn Khaththab antara lain tertulis

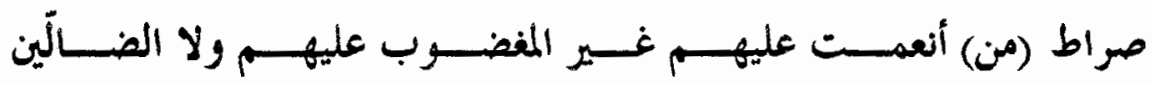

ii. Di dalam mushaf Ibnu Mas'ud antara lain tertulis

Ulul Albab, Vol. 5 No. 2, 2004 


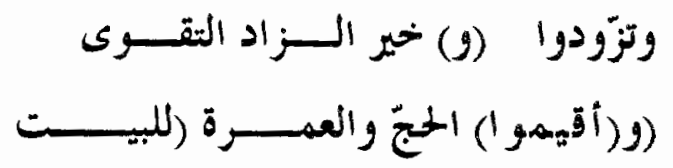

iii. Di dalam mushaf Ibnu Abbas antara lain tertulis

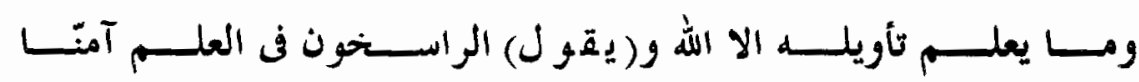

d?

\section{Hadis Nabi saw}

Ada perbedaan di kalangan para tokoh bahasa untuk menyandarkan argumentasinya mengenai kaedah sintaksis bahasa Arab terhadap hadis Nabi saw. Perbedaan itu disebabkan, pertama, karena diperbolehkan meriwayatkan hadis Nabi saw hanya maknanya saja. Kedua, kesalahan ucap (al-lahn) sering terjadi dalam periwayatan hadis, karena sebagian besar perawinya adalah orangorang non-Arab.

Namun kegelisahan di atas menjadi hilang ketika dalam sebuah seminar di Kairo yang disampaikan oleh syaikh Muhammad al-Hidr dengan satu topik" al-istisyhad bi al-hadis fi al-lughah" (menjadikan dasar hadis dalam bahasa). Ia memaparkan beberapa macam hadis beserta syarat-syaratnya sehingga dapat diketahui mana di antara hadis tersebut yang bisa dibuat argumentasi dan yang tidak. Dari hasil seminar itu disepakati bahwa hadis yang bisa dijadikan hujjah/ argumentasi dalam bahasa ialah; (1) Tidak diperbolehkan berargumentasi dengan hadis terkecuali hadis itu sudah dibukukan seperti yang ada pada al-kutub alsittah. (2) Sekalipun hadis itu ada dalam al-kutub al-sittah, ada beberapa persyaratan lain yang harus dipenuhi, yaitu; (a) hadis tersebut mutawatir atau masyhur, (b) hadis yang ada kaitannya dengan ibadah, (c) hadis yang masuk katagori jowami 'al-kalam, (d) hadis yang menjelaskan bahwa Nabi saw berbicara kepada kaumnya dengan bahasa mereka, (e) hadis yang diriwayatkan oleh seorang perawi yang ia tidak pernah melakukan periwayatan hadis dengan maknanya 
saja, dan ( $f$ ) hadis yang diriwayatkan dari berbagai macam sumber, namun lafadznya satu/sama. ${ }^{8}$

\section{Kalam al-‘Arab: Syair dan Prosa}

Selain al-Qur'an dan hadis para linguis Arab dalam membuat kaedah-kaedah bahasa juga menyandarkan argumentasinya kepada kalam al-'Arab yang disampaikan dengan fasih sekalipun itu masih anak-anak atau budak. ${ }^{9} \mathrm{Kalam}$ al'Arab, baik syair maupun prosa yang disampaikan harus melewati perawi yang mu'tabarah, karena untuk menilai al-jarah wa al-ta'dil tidak cukup terbatas pada informan yang fasih tetapi faktor periwayatan juga menjadi penting. Pada umumnya mereka menisbatkan periwayatan (al-sima) kepada al-Sya 'bi (w. 105 H), 'Abdullah bin Ishaq al-Hadrami (w. $117 \mathrm{H}$ ), Qatadah (w. $117 \mathrm{H}$ ), Abu 'Umar (w. $120 \mathrm{H}$ ) 'Isa bin 'Umar (w.149 H) dan Abu 'Umar bin al-'Ala' (w. $154 \mathrm{H}$ ).

Kebanyakan linguis Bashrah dalam membuat kaedah bahasa menetapkan persyaratan yang ketat, yaitu informasi (al-masmu) yang diterima hendaknya disampaikan oleh banyak orang. Sehingga dalam membuat kaedah bahasa mereka memiliki argumen yang kuat. Berbeda dengan linguis Kufah, sekalipun itu disampaikan oleh satu orang mereka akan menjadikan kaedah dalam bahasa. Diantara contoh dalam hal ini adalah tentang kebolehan "Fail" mendahului Fiilnya. Menurut linguis Bashrah tidak membolehkan "Fail”' mendahului fillnya, sementara

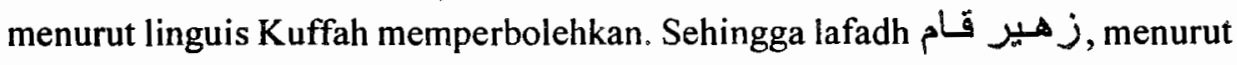

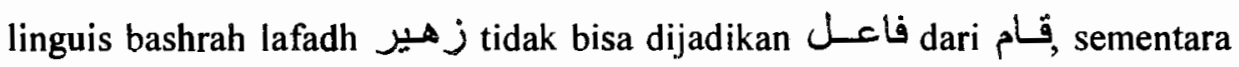

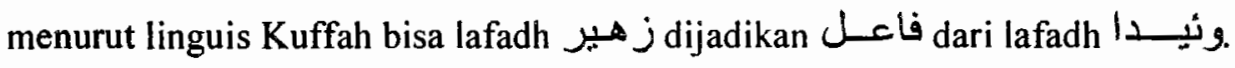
Hal ini karena linguis Kuffah mendasarkan pada syiir al-Zuba';

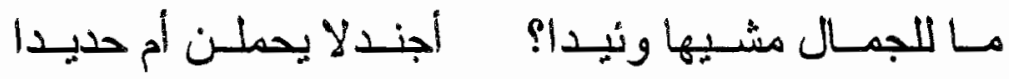

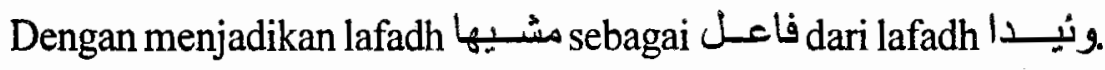


Dari keterangan di atas sesungguhnya para linguis Arab menetapkan beberapa syarat terhadap kalam al- 'Arab yang didengar, di antaranya; Pertama, al-intiga ' al-ijtima ' $i$ (kebersihan sosial), artinya bahasa tersebut tidak bercampur dengan bahasa-bahasa lain. Karena itu, bahasa yang dijadikan pedoman adalah bahasa sastra, bukan bahasa keseharian. Hal ini disebabkan karena bahasa sastra muncul dan ditulis berdasarkan lisan atau pengucapan orang-orang Arab. Jika terjadi perbedaan pengucapan di antara beberapa suku kabilah maka dikembalikan kepada lahjah atau bahasa kabilah yang musta'mal, seperti dalam hadis Nabi saw. Mereka meyakini bahwa bahasa sastra adalah bahasa yang dipakai dalam pemerintahan, dalam penulisan antologi sehingga bahasa sastra identik dengan bahasa Arab fusha. ${ }^{10}$

Kedua, al-intiqa al-makani (kebersihan tempat), artinya bahasa yang direkam harus melalui orang-orang tertentu, yaitu orang-orang yang diyakini tidak berdusta dan fasih dalam pembicaraannya. Dikarenakan jumlah suku kabilah di Jazirah Arab sangat banyak, dan itu pun mereka menggunakan idealek masingmasing maka untuk memastikan bahwa bahasa tersebut adalah bahasa sastra maka para linguis Arab menisbatkan pembicaraan itu kepada Abi 'Amr bin al"Ala', karena sumber ini akan bertemu dan bersambung kepada Nabi saw."

Ketiga, al-intiqa' al-zamani (kebersihan waktu), artinya tidak semua pembicaraan orang-orang Arab, baik berupa syair maupun prosa dapat diterima untuk dijadikan pedoman dalam bahasa. Karena itu, para ahli tata bahasa Arab membuat batasan yang jelas, yaitu bahwa teks-teks yang dapat diterima dan bisa dijadikan pijakan adalah teks-teks yang dihasilkan semenjak masa jahili hingga akhir abad kedua. ${ }^{12}$ Sebab pada masa itu meskipun orang-orang Arab bergaul dengan bangsa-bangsa lain tetapi keaslian bahasa Arab masih dapat terpelihara. Hal ini terbukti pada masa pemerintahan Bani Umayyah, di saat orang-orang Arab menjalin interaksi dengan non-Arab ( $\left.a^{\prime} \hat{a} j i m\right)$ kebanyakan dari mereka yang fasih berbicara bahasa Arab mengalami al-lahn (kekeliruan pengucapan). Karena keadaan ini dikhawatirkan akan merusak bacaan-bacaan al-Qur'an maka tokoh terkenal, Abu al-Aswad al-Du'ali melakukan penulisan tata bahasa (nahw). Kemudian embrio ini menjadi landasan perkembangan nahw berikutnya, baik di Basrah maupun di Kufah. Selain itu, karena di era Banî Umyyah banyak bermunculan fitnah dan madzhab (aliran) maka atas kebijakan 'Umar bin 'Abd al-Aziz dilakukanlah kodifikasi hadis sebagai rujukan umat Islam. 
Pada masa pemerintahan Khâlid bin Yazîd bin Mu'awiyah di mana ia sangat gemar terhadap karya-karya Yunani maka digerakkanlah penerjemahan beberapa ilmu pengetahuan ke dalam bahasa Arab, seperti ilmu kedokteran, kimia dan sejarah. ${ }^{13}$ Secara umum, dinasti Banî Umayyah banyak berjasa dalam pembangunan berbagai bidang, baik politik maupun sosial kebudayaan. Dalam bidang politik, Banî Umayyah menyusun tata pemerintahan yang baru untuk memenuhi tuntutan perkembangan wilayah dan administrasi kenegaraan yang semakin komplek. Selain mengankat Majelis Penasehat sebagai pendamping, khalifah Banî Umayyah dibantu beberapa kuttâb (secretaries) untuk pelaksanaan tugas; (1) kâtib al-rasâil, (2) kâtib al-kharraj, (3) kâtib al-jundi, (4) kâtib al-syurthah, dan (5) kâtib al-qudhât. ${ }^{14}$ Dalam kegiatan administrasi ini mereka menggunakan bahasa Arab sebagai bahasa resmi, baik dalam percakapan maupun koresprodensi.

\section{Penutup}

Ushul al-nahwi merupakan dasar pijakan dan sandaran dalam merumuskan dasar bangunan sintaksis bahasa Arab. Karena setiap bahasa harus memiliki susunan yang teratur dan berpola sehingga membentuk suatu keseluruhan yang bermakna dan berfungsi. Sistem ini dibentuk oleh sejumlah unsur atau komponen yang satu dengan lainnya berhubungan secara fungsional. Karena itu, dalam bahasa Arab kajian mengenai ushul al-nahwi mempunyai rujukan yang kuat sehingga wujud bahasa yang disampaikan akan memberikan pemahaman yang jelas. Ushul al-nahwi tersebut di antaranya adalah al-Qur'an, hadis Nabi saw dan kalam al-'Arab, baik berupa syair maupun prosa.

\section{Endnotes}

1 Baca Syauqi Dhaif, al-Madaris al-Nahwiyah (Kairo: Dar al-Ma'arif, 1988), h. 154.

2 Ahmad Sayim al-Hamshi dan Muhammad Ahmad Qasim, al-lqtirahfi 'Ilmi Ushul alNahwi lil Imam al-'Allamah Jalaluddin 'Abd al-Rahman al-Suyuthi (tp, 1988), h. 21.

3 Abdul Chaer, Linguistik Umum (Jakarta: Rineka Cipta, 1994), h. 35.

4 Syihab al-Namr Isma' il, Manhaj al-Suyuthifi Ushul al-Nahwi min Hilal Kitabihi alIqtirah (Kairo: Matba' al-Husain al-Islamiyah, 1994), h. 55.

Ulul Albab, Vol. 5 No. 2, 2004 
3 Tamam Hassan, al-Ushul: Dirasatun Istimolojiyyah li al-Fikri al-Lughawi 'Inda al'Arab (Kairo: al-Hayyiah al-Mishriyyah al-"Ammah li al-Kuttab, 1982), h. 71.

6 Ibid., 97.

7 Ibid., 98.

8 Muhammad Fahmi 'Umar, al-Hadits al-Syarif fi Nahw Ibn Hisyam (Kairo: al'Ummanah; 1991), h. 29.

9. Abd al-Rahman Jalal al-Din al-Suyuthi, al-Mizhar fl 'Ulum al-Lughah wa 'Anwa'uha (Beirut: al-Maktabah al-'Ashriyah, 1987), h. 139.

10 Tamam Hassan, op. cit., h. 94.

"I Ibid.,

12 Ibid., h. 95.

13 Ahmad al-Iskandari dan Musthafa 'Inany, al-Wasith fi al-Adab al-'Araby (Beirut: Dar al-Ma'arif, 1978), h. 137.

14 Mufrodi, Islam di Kawasan Kebudayaan Arab (Jakarta: Logos, 1997) h. 82.

\section{Bibliography}

Syauqi Dhaif, al-Madaris al-Nahwiyah (Kairo: Dar al-Ma'arif, 1988)

Ahmad Sayim al-Hamshi dan Muhammad Ahmad Qasim, al-Iqtirah fi ' $l l m i$

Ushul al-Nahwi lil Imam al-'Allamah Jalaluddin 'Abd al-Rahman al-

Suyuthi (tp, 1988)

Abdul Chaer, Linguistik Umum (Jakarta: Rineka Cipta, 1994)

Syihab al-Namr Isma'il, Manhaj al-Swyuthi fi Ushul al-Nahwi min Hilal

Kitabihi al-Iqtirah (Kairo: Matba' al-Husain al-Islamiyah, 1994)

Tamam Hassan, al-Ushul: Dirasatun Istimolojiyyah li al-Fikri al-Lughawi 'Inda al-'Arab (Kairo: al-Hayyiah al-Mishriyyah al-'Ammah li al-Kuttab, 1982)

Muhammad Fahmi 'Umar, al-Hadits al-Syarif fi Nahw Ibn Hisyam (Kairo: al'Ummanah; 1991)

'Abd al-Rahman Jalal al-Din al-Suyuthi, al-Mizhar fi 'Ulum al-Lughah wa 'Anwa 'uha (Beirut: al-Maktabah al-'Ashriyah, 1987)

Ahmad al-Iskandari dan Musthafa 'Inany, al-Wasith fi al-Adab al- Araby (Beirut: Dar al-Ma'arif, 1978)

Mufrodi, Islam di Kawasan Kebudayaan Arab (Jakarta: Logos, 1997) 